\title{
Spasmer i beina - skade i nakken
}
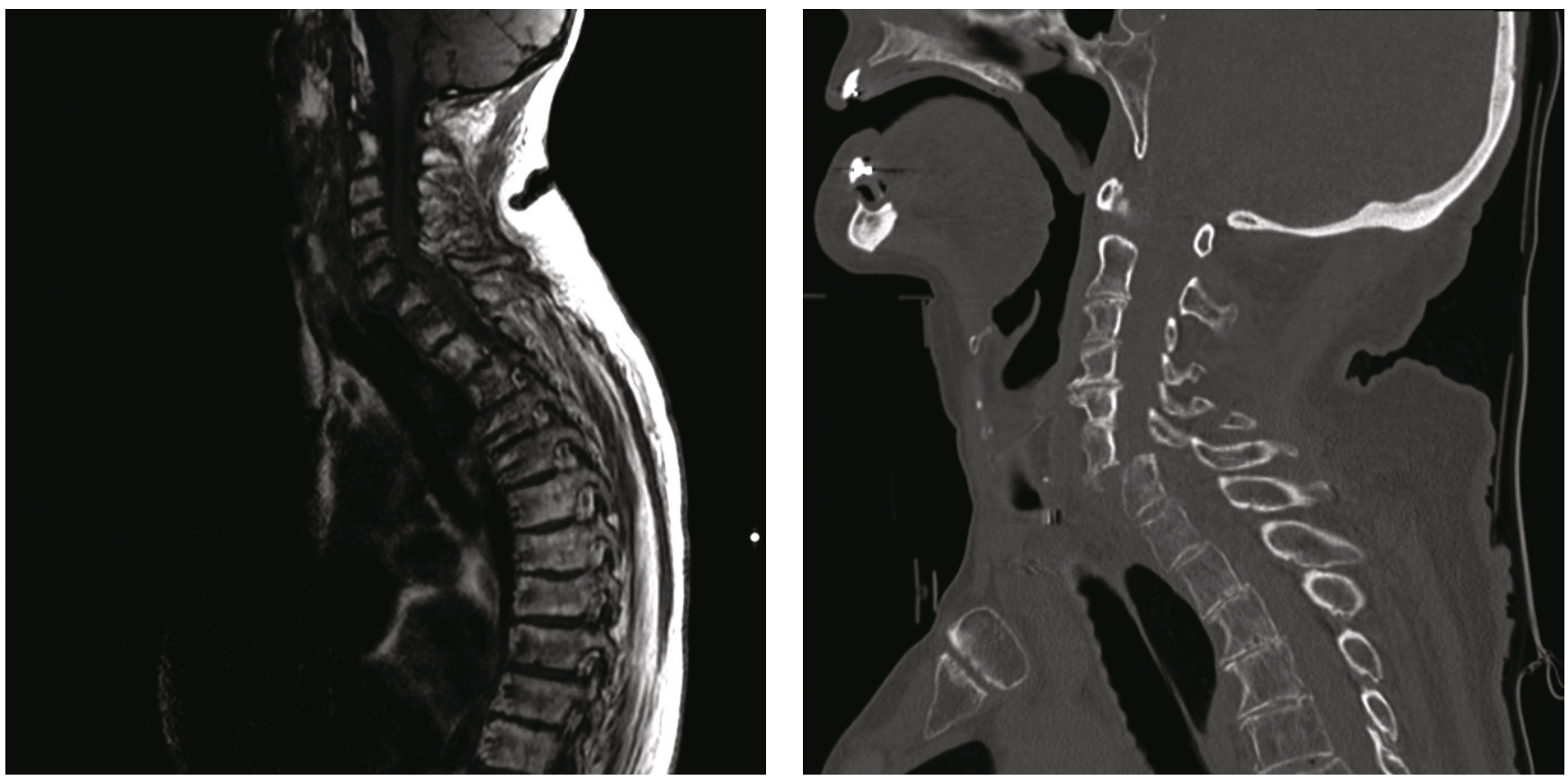

En kvinne i 80-årene ble funnet på gulvet $\mathrm{i}$ sitt hjem. Hun var hypoterm, forvirret og hadde smerter i nakken. Ambulansepersonalet observerte rykninger i høyre bein. Pasienten fikk forbigående respirasjonsstans med ledsagende bevissthetstap og ble innlagt ved medisinsk avdeling. Grov nevrologisk undersøkelse ved innkomst viste normale funn. Hun løftet på armer og bein og gikk med støtte. Nakkefunksjonsundersøkelse er ikke beskrevet i journalen.

EKG viste rask atrieflimmer. Hun ble undersøkt med CT av hodet, blodprøver, urinstiks, blodgass, rytmeovervåkning og EEG for mistanke om infeksjon, arytmi eller epileptisk anfall. CT av hodet viste residiv av et tidligere operert meningeom frontalt på høyre side samt et nytt meningeom parietalt på venstre side. EEG tatt to dager etter innleggelsen viste ikke epileptiform aktivitet. Nevrologen som så spasmene under EEGregistreringen overveide dystone anfall. Imidlertid hadde de hyppige høyresidige rykningene samme fleksjonsmønster som ved invertert plantarrefleks, vist ved Babinskis tegn (video). Rykningene kom stadig spontant, av og til også på venstre side, og kunne utløses ved lett berøring av huden. Nevrologen fikk derfor mistanke om myelo- pati. Ved ny nevrologisk undersøkelse hadde pasienten redusert kraft for håndtrykk bilateralt og var spastisk i underekstremitetene. Akutt MR viste cervikal myelopati (bildet til venstre), og CT av nakken viste luksasjonsfraktur i nivå C6/C7 med avklemming av ryggmargen (bildet til høyre). Ved overflytting til nevrokirurgisk avdeling var hun tetraparetisk, men hadde bevart sensibilitet. Hun ble øyeblikkelig operert med bakre fiksasjon og etter to dager reoperert med fremre fiksasjon i nivå C6/C7. Rykningene i føttene forsvant, men hun hadde vedvarende paralyse distalt $i$ bein og armer og grad 2-4/5 pareser proksimalt. Kvinnen døde kort tid etter.

Ved akutt sykdom av ukjent årsak bør man utføre grundig nevrologisk undersøkelse også av nakken. Spontant invertert plantarrefleks er sjelden. Det bør gi mistanke om sykdom i spinalkanalen, og bildeundersøkelser bør da inkludere ryggmarg.

Pasientens pårørende har gitt samtykke til at artikkelen blir publisert.

\section{Ivar Otto Gjerde}

Marte Helene Bjørk

marte-helene.bjork@helse-bergen.no
Ivar Otto Gjerde (f. 1947) er spesialist i nevrologi og i klinisk nevrofysiologi og er overlege på Nevrologisk avdeling. Haukeland universitetssykehus.

Forfatter har fylt ut ICMJE-skjemaet og oppgir ingen interessekonflikter.

Marte Helene Bjørk (f. 1980) har ph.d. i nevrovitenskap, er lege i spesialisering ved Nevrologisk avdeling, Haukeland universitetssykehus og postdoktor ved Universitetet i Bergen.

Forfatter har fylt ut ICMJE-skjemaet og oppgir ingen interessekonflikter.

Mottatt 1.7. 2013, første revisjon innsendt 17.1.2014, godkjent 4.2. 2014. Redaktør: Matilde Risopatron Berg. 